\title{
Controls on snowmelt water mean transit times in northern boreal catchments
}

\author{
Steve W. Lyon, ${ }^{1 *}$ Hjalmar Laudon, ${ }^{2}$ Jan Seibert, ${ }^{1,3}$ Magnus Mörth, ${ }^{4}$ Doerthe Tetzlaff ${ }^{5}$ \\ and Kevin H. Bishop ${ }^{6}$ \\ ${ }^{1}$ Department of Physical Geography and Quaternary Geology, Stockholm University, Stockholm, Sweden \\ ${ }^{2}$ Department of Forest Ecology and Management, SLU, Umeå, Sweden \\ ${ }^{3}$ Department of Geography, University of Zurich, Zurich, Switzerland \\ ${ }^{4}$ Department of Geology and Geochemistry, Stockholm University, Stockholm, Sweden \\ 5 School of Geosciences, University of Aberdeen, Aberdeen, Scotland \\ ${ }^{6}$ Department of Aquatic Sciences and Assessment, SLU, Uppsala, Sweden
}

\begin{abstract}
:
Catchment-scale transit times for water are increasingly being recognized as an important control on geochemical processes. In this study, snowmelt water mean transit times (MTTs) were estimated for the 15 Krycklan research catchments in northern boreal Sweden. The snowmelt water MTTs were assumed to be representative of the catchment-scale hydrologic response during the spring thaw period and, as such, may be considered to be a component of the catchment's overall MTT. These snowmelt water MTTs were empirically related to catchment characteristics and landscape structure represented by using different indices of soil cover, topography and catchment similarity. Mire wetlands were shown to be significantly correlated to snowmelt MTTs for the studied catchments. In these wetlands, shallow ice layers form that have been shown to serve as impervious boundaries to vertical infiltration during snowmelt periods and, thus, alter the flow pathways of water in the landscape. Using a simple thought experiment, we could estimate the potential effect of thawing of ice layers on snowmelt hydrologic response using the empirical relationship between landscape structure (represented using a catchment-scale Pe number) and hydrologic response. The result of this thought experiment was that there could be a potential increase of 20-45\% in catchment snowmelt water MTTs for the Krycklan experimental catchments. It is therefore possible that climatic changes present competing influences on the hydrologic response of northern boreal catchments that need to be considered. For example, MTTs may tend to decrease during some times of the year due to an acceleration in the hydrologic cycle, while they tend to increase MTTs during other times of the year due to shifts in hydrologic flow pathways. The balance between the competing influences on a catchment's MTT has consequences on climatic feedbacks as it could influence hydrological and biogeochemical cycles at the catchment scale for northern latitude boreal catchments. Copyright (c) 2010 John Wiley \& Sons, Ltd.
\end{abstract}

KEY WORDS mean transit time; catchment similarity; boreal systems; climate change; wetlands; snowmelt

Received 10 August 2009; Accepted 6 November 2009

\section{INTRODUCTION}

The hydrologic response of a catchment is typically considered to be forced by the climate (e.g. precipitation and solar radiation) and controlled by the structure of the catchment (e.g. geology and topography). Much hydrologic research, therefore, focuses on connecting catchment-scale hydrologic response to landscape controls with mean transit time (MTT) as an indicator of catchment-scale hydrologic response. Such connections might form the basis for predictive tools of hydrological catchment behaviour for ungauged basins (McDonnell et al., 2007).

Estimation of the transit-time distribution and the associated MTT at the catchment scale using inverse techniques such as the lumped parameter convolution approach (i.e. McGuire and McDonnell, 2006) remain popular despite several shortcomings. While originally

\footnotetext{
* Correspondence to: Steve W. Lyon, Department of Physical Geography and Quaternary Geology, Stockholm University, 10691 Stockholm, Sweden. E-mail: steve.lyon@natgeo.su.se
}

developed for quasi-steady-state groundwater systems, this time-invariant approach of linear superposition of system responses has been useful in many surface water studies (Kirchner et al., 2001; McGuire et al., 2005; Lyon et al., 2008; Hrachowitz et al., 2009a). Variable flow approaches have been suggested (e.g. Niemi, 1977; Yurtsever and Payne, 1986; Rodhe et al., 1996) but have seen limited acceptance because of their mathematical complexity. Practical limitations to their application in multiple, nested catchment systems due to increased data requirements (i.e. observation of both tracer and discharge at several locations) could also exist. In addition, when the variable part of a flow system is small compared to the system as a whole, the information attainable from adopting a variable flow approach is similar to that under quasi-steady flow approximation (Maloszewski and Zuber, 1993). There are also difficulties associated with characterizing catchment inputs for a lumped parameter convolution approach to determine transit-time distributions and MTTs as rainfall or snowmelt is often highly variable in space and time for 
tracer composition and amount (McGuire and McDonnell, 2006). All these factors lead to some uncertainties associated with MTTs estimated using lumped parameter convolution approaches. Regardless, the lumped parameter approach offers a simple methodology to investigate how water moves through the landscape by convoluting an observable albeit simplified input signal into an observed output signal.

MTTs for small catchments have been described to be controlled by two main factors: topography and typology. These are the first two Ts of the Buttle's (2006) $\mathrm{T}^{3}$ template. The third $\mathrm{T}$, topology, deals primarily with stream or channel network configurations that are often assumed negligible (for simplicity) in small-catchment systems or with the connectivity across landscape units. McGuire et al. (2005) at HJ Andrews (Western Cascades, USA) and McGlynn et al. (2003) in Maimai (New Zealand) showed the importance of topographic control. In contrast, Soulsby et al. (2006a,b) and Tetzlaff et al. (2009a) found that in recently glaciated landscapes such as in Scotland, soil cover and hydrological characteristics (typology) are a more important control on catchment-scale MTTs. These two controls might be related through geomorphology and the evolution of the landscape (e.g. topography leads to soil formation which, in turn, influences topography) at long time scales. This has led recently to more holistic approaches to catchment hydrology such as Buttle's $\mathrm{T}^{3}$ template (Buttle, 2006), which recognizes that all components of a natural system (hydrology, ecology, topography, etc.) develop in concert (Troch et al., 2008). Typically, the co-evolution of topography and soils as a control on catchment response occurs over such long (i.e. geologic) time scales that it is considered static over the time frame of human observation (of which catchment-scale studies tend to be limited). While this is certainly true for most warm and temperate climates, it does not necessarily hold in colder regions.

In cold regions, ice formation in soils influences the distribution of hydrologic pathways (Woo et al., 2008). Such ice layers may be permanent (i.e. permafrost) or more transient such that their position (existence) fluctuates seasonally and annually. For example, in arctic and subarctic systems, ice layers at the interface of the organic and mineral soils have often been cited as the main cause of lateral runoff (Kane et al., 1981; Roulet and Woo, 1988; McNamara et al., 1997), with much research emphasizing their role in water storage and restriction of transmittance properties (Santeford, 1979; Slaughter and Kane, 1979; Hinzman et al., 1993; McNamara et al., 1998). Seasonal fluctuations in the active layer for northern systems has been observed to directly influence the hydrologic response at the hillslope and catchment scales (Carey and Woo, 2001; Yamazaki et al., 2006; Woo et al., 2008). In addition, a long-term change in permafrost influences the hydrologic response. Recently, Lyon et al. (2009) and Lyon and Destouni (2009) used long records of observed streamflow and recession flow analysis to estimate catchment-scale changes in permafrost position.
This technique connected changes in hydrologic response to changes in catchment structure.

In boreal systems, soil ice in mire wetlands has been shown to influence the pathways water takes in the landscape (e.g. Spence and Woo, 2006). Specifically, Laudon et al. (2007) observed that the proportion of wetland and median catchment area influenced the runoff generation mechanisms in several small catchments located in boreal northern Sweden. As the formation of these ice layers is sensitive to climatic variability and change, it reasons that climate change may influence catchment MTT, particularly during spring thawing in boreal systems not only through changes in forcing but also through changes in structure. On the basis of this previous work, we consider the role of catchment characteristics (e.g. topographic and landscape) and structure in relation to the hydrologic response for these catchments during spring melt periods. The main goal of this study was to estimate the MTTs for snowmelt water moving through the 15 Krycklan catchments located in northern boreal Sweden. We also investigated empirical links between several topographic and landscape factors of the 15 catchments and the snowmelt MTTs estimated from stable water isotope sampling. In addition, we developed a simple empirical model based on a catchment-scale similarity parameter. This empirical model allowed us to formulate a simple thought experiment to speculate about the potential effects of climate change on wetland soil ice layers and the influence this could have on the hydrologic response of these northern boreal catchments during spring melt. Primarily, we test the hypothesis that effectively deeper wetlands during spring thaw could lead to increased snowmelt water MTTs at the catchment scale due to deeper flow pathways that, in effect, dampen the system response of conservative solutes.

\section{STUDY AREA}

The Krycklan Catchment Study contains 15 nested research catchments within the Vindeln Experimental Forests $\left(64^{\circ} 140^{\prime} \mathrm{N}, 10^{\circ} 460^{\prime} \mathrm{E}\right)$ that are approximately $50 \mathrm{~km}$ northwest of Umeå, Sweden (Figure 1). These 15 boreal catchments range in size from 0.03 to $67 \mathrm{~km}^{2}$. This region is climatically typified by short summers and long winters. Snow covers the ground on average for 171 days, from the end of October to the beginning of May (Ottosson-Löfvenius et al., 2003). The mean annual precipitation and temperature are $646 \mathrm{~mm}$ and $+1.8{ }^{\circ} \mathrm{C}$ respectively, with about $50 \%$ of the annual precipitation falling as snow.

The upland parts of the main catchment are mainly forested with Norway spruce (Picea abies) in low-lying areas and Scots pine (Pinus sylvestris) in upslope areas. Large patches of mire wetlands predominantly in the upper part of the main catchment are also present. In the lower regions, Norway spruce and Scots pine are also the dominant tree species, but deciduous trees and shrubs are more common along the stream channels. 


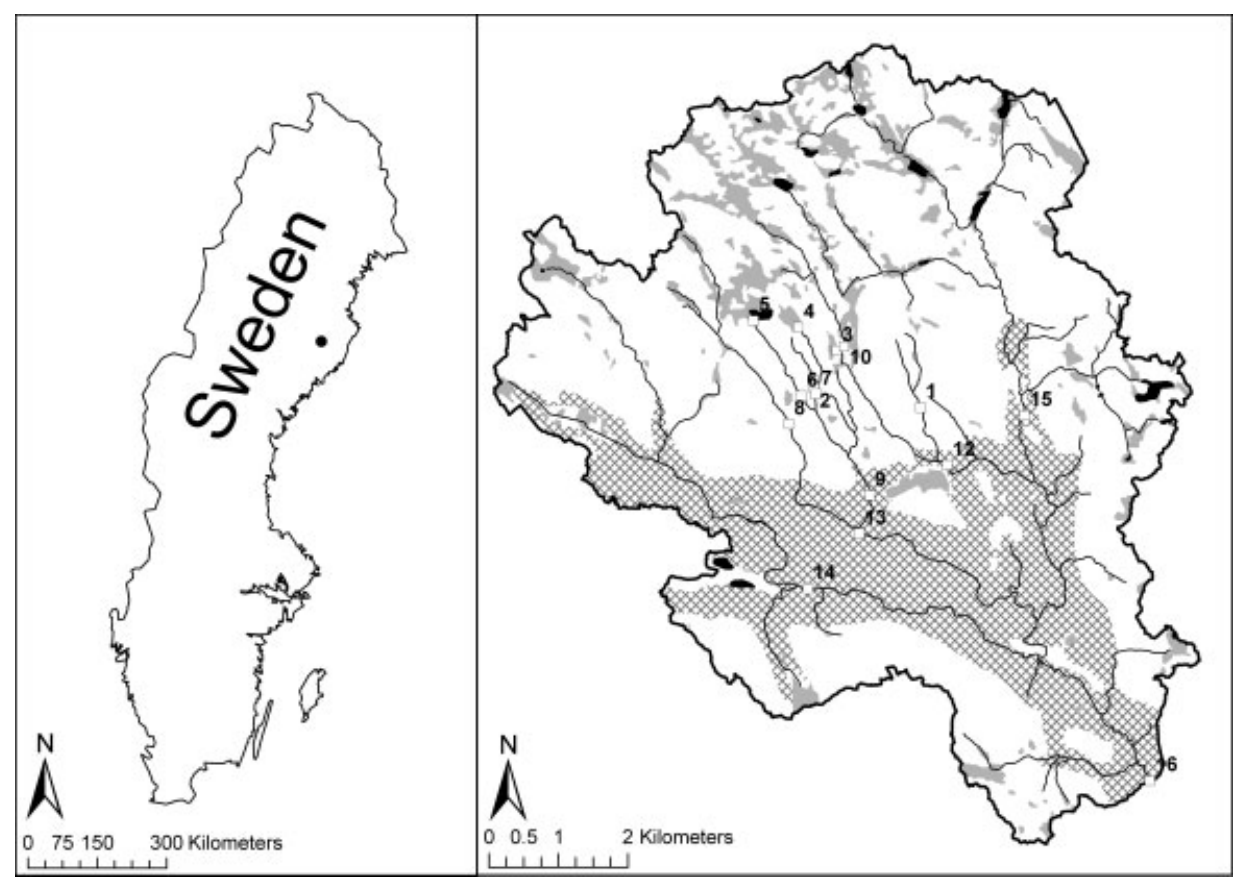

Figure 1. Site map showing the location of the Krycklan Catchment Study in northern Sweden and the outlets of the 15 Krycklan catchments used in this study. The largest catchment outlet (site 16) is located at $64^{\circ} 12^{\prime} \mathrm{N}$ and $19^{\circ} 52^{\prime} \mathrm{E}$. Lakes are in black, mire wetlands are in grey and silt soils are indicated with cross hatching

Small areas of agricultural fields are found in the lower part of the catchment. Geologically, these catchments are located on the Fennoscandian shield and overlay gneissic bedrock (Buffam et al., 2007). Glacial tills in the upper portion of the main catchment give way to deeper sorted sediments towards the catchment outlet (Figure 1). Subsurface pathways dominate the forested sites with overland flow rarely occurring due to the high infiltration capacity of the till soils (Bishop et al., 1990; Laudon et al., 2004). Well-developed iron-podzol soils are common and, in the lower reaches, larger streams have incised channels carving through finegrained floodplain sediments (Buffam et al., 2007).

\section{METHODS AND MATERIALS}

\section{Time series of isotopic data}

The present study makes use of data collected in conjunction with previous and on-going field campaigns spanning the last 20 years at the research catchments as part of the Krycklan Catchment Study. The details of the field techniques and sampling strategies used in these various studies are provided to a large extent in Bishop et al. (1990); Ågren et al. (2007); Laudon et al. (2007) and Köhler et al. (2008). In the current study, we use time series of $\delta^{18} \mathrm{O}$ observed in snowmelt and streamflow water for the 15 nested Krycklan catchments. Analysis of collected water samples was performed using a GASBench II (Finnigan MAT) connected to a Delta plus mass spectrometer (Finnigan MAT). Data was normalized so that the difference between Standard Light Antarctic Precipitation (SLAP) and Standard Mean Ocean Water (SMOW) was $-55.5 \%$ (Coplen, 1995). The accuracy was always better than $0 \cdot 2 \%$ obased on in-house qualitycontrol measurements. These time series of $\delta^{18} \mathrm{O}$ values for the input (snowmelt) and output (streamflow) signal from 15 nested catchments under similar geologic and climatic settings provide a unique dataset to observe snowmelt water MTTs.

The output time series is based on 1 year of streamflow $\delta^{18} \mathrm{O}$ values for all 15 catchments for the year 2004 (Figure 2). Frequent sampling was conducted during snowmelt periods (one sample collected at each catchment outlet about every third day in April and May) for 2004, while monthly sampling was used during the remainder of the year. For each catchment, there was a clear response in streamflow $\delta^{18} \mathrm{O}$ values during the spring melt period (Table I) indicated by a significant difference between the maximum and minimum observed streamflow $\delta^{18} \mathrm{O}$ values.

Two input time series are considered on the basis of a combination of streamflow and snowmelt $\delta^{18} \mathrm{O}$ values available for the 2004 sampling season (see Laudon et al., 2007 for details). Note that, currently, no rainfall $\delta^{18} \mathrm{O}$ values are available during the 2004 snow-free period. This adds some uncertainty to the representation of input water to the catchments after the snowmelt period. There was relatively small spatial variability but considerable temporal variability in snowmelt water $\delta^{18} \mathrm{O}$ values (Laudon et al., 2007). Observed snowmelt water $\delta^{18} \mathrm{O}$ values in the first melt water leaving the snow pack were $-18 \cdot 1,-18 \cdot 3$ and $-17 \cdot 3 \%$ in open field, open canopy and closed canopy respectively (Laudon et al., 2007). At the end of the melt season, the corresponding values were $-15 \cdot 7,-15.8$ and $-15.2 \%$, suggesting a large fractionation during snow melt (Laudon et al., 2007). Laudon et al. (2007) report average snowmelt $\delta^{18} \mathrm{O}$ 

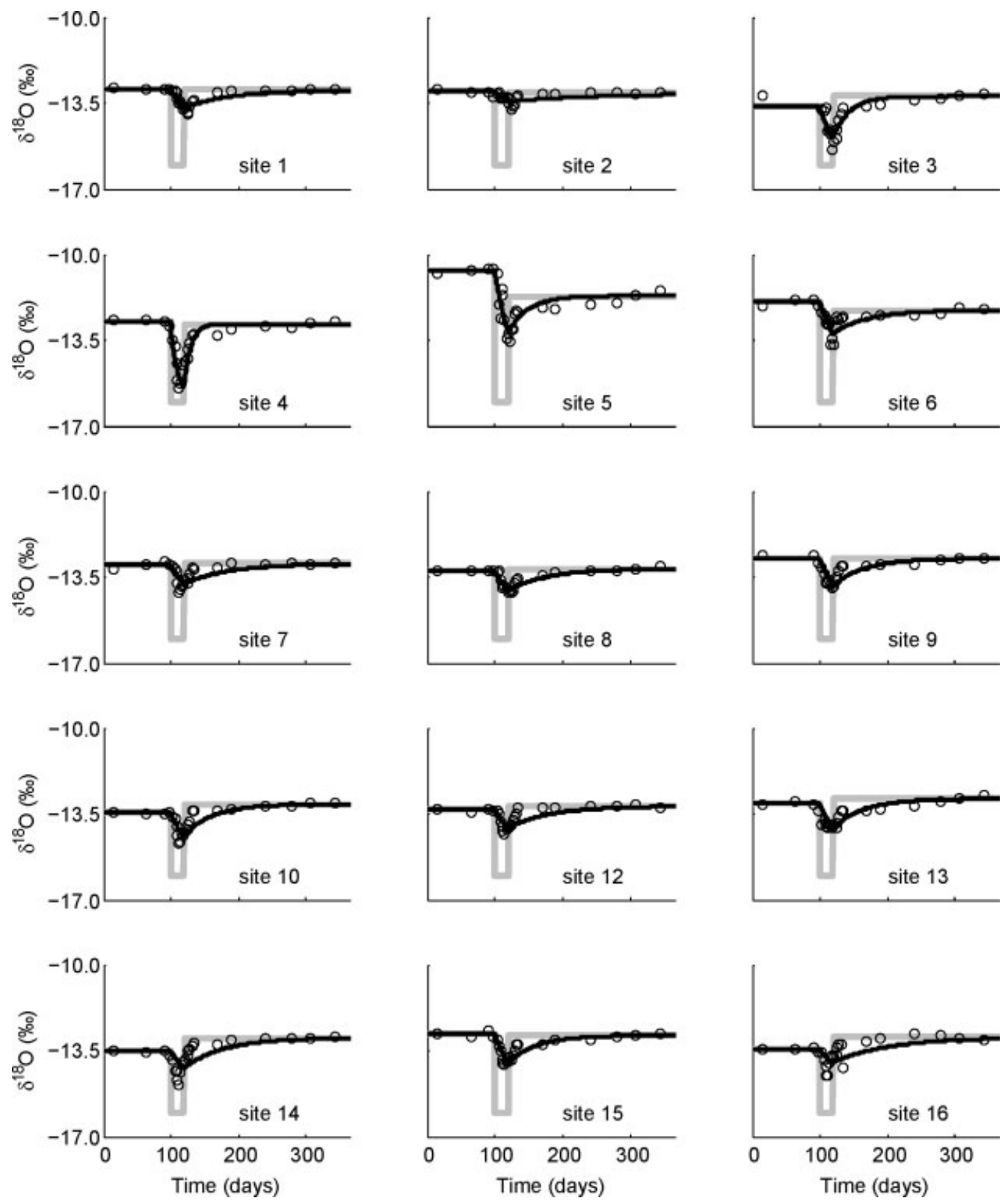

Figure 2. Snowmelt water input (solid grey line) and streamflow water output (dots) observed for each of the 15 Krycklan catchments along with the best-fitting lumped parameter convolution model predicted output (solid black line) from 1 January 2004 through 31 December 2004 . Input and modelled output shown only for representing snow melt water as a constant isotopic value

values from volume-weighted snowmelt water of $-16 \cdot 1$, -16.0 and $-15.9 \%$ for open field snow lysimeters, open canopy snow lysimeters and closed canopy snow lysimeters, respectively, over the entire 20 days of the snowmelt season (9 April 2004 through 29 April 2004). For simplicity in this study, we consider two different snowmelt water isotopic scenarios. The first assumes that snowmelt water has a constant isotopic value of $-16.0 \%$ for all of the 15 Krycklan catchments over the 20 days of observed snowmelt. The second allows for a linear enrichment of snow melt water with respect to $\delta^{18} \mathrm{O}$ values over the melt period. Thus, snow melt water starts with an $\delta^{18} \mathrm{O}$ value of $-17.9 \%$, representing the average of the first melt water leaving the snow pack observed by Laudon et al. (2007) and enriches linearly to a value of $-15.6 \%$ representing the average of the last observed melt water. These snowmelt $\delta^{18} \mathrm{O}$ values may be considered as pulses of input snowmelt water to the Krycklan catchments.

To trace these pulses of water through each catchment, we superimpose these signals onto an isotopic signal more representative of non-melt-period streamflow water before and after spring melt. To represent the non-melt period before the onset of spring melt for each catchment, we take the average of the first three streamflow $\delta^{18} \mathrm{O}$ values for each catchment. The first three samples cover a time period of roughly 100 days for each catchment. To represent the non-melt period after the cessation of spring melt for each catchment, we take the average of the last three streamflow $\delta^{18} \mathrm{O}$ values observed for each catchment. There is a time lag between the end of the snowmelt period and the first of these three 
Table I. Observed range in streamflow $\delta^{18} \mathrm{O}$ values and the estimated MTTs from the lump parameter convolution using both a constant isotopic value for snowmelt water and a linear enrichment over the melt period

\begin{tabular}{|c|c|c|c|c|c|c|c|c|}
\hline \multirow[t]{2}{*}{ ID } & \multirow{2}{*}{$\begin{array}{l}\text { Maximum } \\
\text { observed } \delta^{18} \mathrm{O}\end{array}$} & \multirow{2}{*}{$\begin{array}{c}\text { Minimum } \\
\text { observed } \delta^{18} \mathrm{O}\end{array}$} & \multicolumn{3}{|c|}{ Constant snowmelt isotopic value } & \multicolumn{3}{|c|}{ Linear enrichment snowmelt isotopic value } \\
\hline & & & MTT (days) & $\begin{array}{c}5 \text { th/95th } \\
\text { percentiles (days) }\end{array}$ & NSE & MTT (days) & $\begin{array}{c}5 \text { th/95th } \\
\text { percentiles (days) }\end{array}$ & NSE \\
\hline Site 1 & $-12 \cdot 8$ & $-14 \cdot 0$ & $67(60-75)$ & $5 / 201$ & 0.83 & $91(80-104)$ & $5 / 273$ & $0 \cdot 77$ \\
\hline Site 2 & $-12 \cdot 9$ & $-13 \cdot 8$ & $133(110-167)$ & $7 / 398$ & 0.48 & $180(148-230)$ & $9 / 539$ & 0.43 \\
\hline Site 3 & $-13 \cdot 1$ & $-15 \cdot 4$ & $25(20-31)$ & $1 / 75$ & $0 \cdot 81$ & $40(33-50)$ & $2 / 120$ & 0.76 \\
\hline Site 4 & $-12 \cdot 7$ & $-15 \cdot 5$ & $10(9-12)$ & $1 / 30$ & 0.84 & $19(16-23)$ & $1 / 57$ & 0.79 \\
\hline Site 5 & $-10 \cdot 6$ & $-13 \cdot 6$ & $31(28-35)$ & $2 / 93$ & 0.83 & $38(35-43)$ & $2 / 114$ & $0 \cdot 82$ \\
\hline Site 6 & $-11 \cdot 9$ & $-13 \cdot 7$ & $51(44-59)$ & $3 / 153$ & 0.68 & $65(57-75)$ & $3 / 195$ & 0.68 \\
\hline Site 7 & $-12 \cdot 9$ & $-14 \cdot 1$ & $67(54-88)$ & $3 / 201$ & 0.55 & $93(74-121)$ & $5 / 279$ & 0.53 \\
\hline Site 8 & $-13 \cdot 0$ & $-14 \cdot 2$ & $57(51-64)$ & $3 / 171$ & 0.85 & $81(72-91)$ & $4 / 243$ & 0.81 \\
\hline Site 9 & $-12 \cdot 6$ & $-13 \cdot 9$ & $45(39-54)$ & $2 / 135$ & 0.69 & $62(54-72)$ & $3 / 186$ & 0.70 \\
\hline Site 10 & $-13 \cdot 1$ & $-14 \cdot 7$ & $42(33-56)$ & $2 / 126$ & 0.67 & $64(51-84)$ & $3 / 192$ & 0.64 \\
\hline Site 12 & $-13 \cdot 1$ & $-14 \cdot 3$ & $61(49-80)$ & $3 / 183$ & 0.59 & $88(70-115)$ & $5 / 264$ & 0.55 \\
\hline Site 13 & $-12 \cdot 8$ & $-14 \cdot 1$ & $45(38-54)$ & $2 / 135$ & 0.68 & $62(54-73)$ & $3 / 186$ & 0.72 \\
\hline Site 14 & $-12 \cdot 9$ & -14.9 & $59(1-106)$ & $3 / 177$ & 0.38 & $84(57-145)$ & $4 / 252$ & 0.37 \\
\hline Site 15 & $-12 \cdot 7$ & $-14 \cdot 0$ & $43(37-49)$ & $2 / 129$ & 0.77 & $58(52-66)$ & $3 / 174$ & 0.78 \\
\hline Site 16 & $-12 \cdot 8$ & $-14 \cdot 5$ & $81(54-140)$ & $4 / 243$ & $0 \cdot 38$ & $111(76-193)$ & $6 / 333$ & 0.35 \\
\hline
\end{tabular}

The values in parentheses show the range of MTTs obtained increasing in the minimized least squares statistic by $5 \%$ as a metric objective function convergence. The corresponding 5th/95th percentiles of the exponential distributions and the NSE for the 15 Krycklan catchments are also shown.

streamflow $\delta^{18} \mathrm{O}$ values for each catchment of about 160 days. The resulting input time series of $\delta^{18} \mathrm{O}$ values resembles a unique saw-tooth pattern for each of the 15 Krycklan catchments (Figure 2). This methodology for representing the input signal is similar to that applied by Lyon et al. (2008) for estimating an event-scale transittime distribution in response to an extreme rainfall event. Our current method differs from Lyon et al. (2008) in that the pre-melt signal is different than that used to represent the post-melt signal; thus, we do not assume that there is a cyclic pattern where the input signal at the beginning of the year matches the signal at the end of the year (at least at the scale of 1 year) intrinsic to the isotopic inputs to these catchments. As rainfall occurs during the post-melt period, there is likely an influence of this rain water's isotopic composition on the input signal to the catchments. Without direct measures of this rain water isotopic composition, however, we are unable to directly represent its influence on the input signal. By using the last three stream samples collected a long time after the cessation to snowmelt (here, 160 days after the end of snow melt to the end of the year), we can approximate the influence of this water on the input signal. This, of course, adds to the uncertainty associated with the absolute MTTs estimated from these composite input signals.

\section{Estimating snowmelt water MTT}

Snowmelt water MTTs were modelled using the lumped parameter convolution approach. See McGuire and McDonnell (2006) for a recent review of the methodology. The lumped parameter convolution approach uses a weighting or kernel function, $g(\tau)$, to describe the transport of a conservative tracer through a catchment. Using this approach, an output signal (streamflow in this study) at any time, $\gamma_{\text {out }}(t)$, consists of the input signal (combinations of snowmelt streamflow in this study) of the tracer, $\gamma_{\text {in }}(t-\tau)$, applied uniformly over the catchment in the past $(t-\tau)$, which becomes lagged according to its transit-time distribution, $g(\tau)$ (Barnes and Bonell, 1996; Kirchner et al., 2000):

$$
\gamma_{\text {out }}(t)=\int_{0}^{\infty} g(\tau) \gamma(t-\tau) \mathrm{d} \tau
$$

where $\tau$ are the lag times between input and output signals. To limit the amount of parameter calibration in applying the lumped parameter approach, we used a mathematical function to express the transit-time distribution in this study. Several distributions are possible, but we have restricted ourselves to the widely used exponential distribution as it is parsimonious in the number of fitted parameters. Following Maloszewski and Zuber (1982), this exponential transit-time distribution, $g(\tau)$, has the form:

$$
g(\tau)=\frac{1}{\tau_{\mathrm{m}}} \exp \left(\frac{-\tau}{\tau_{\mathrm{m}}}\right)
$$

where $\tau_{\mathrm{m}}$ denotes the first moment of the transit-time distribution or the MTT of the transit-time distribution. The exponential transit-time distribution describes a catchment with flow times that are distributed exponentially, including pathways with very short transit times (McGuire and McDonnell, 2006), and represent the apparent behaviour of a well-mixed linear reservoir (Maloszewski and Zuber, 1982; Rodhe et al., 1996). To fit the exponential transit-time distribution parameter, $\tau_{\mathrm{m}}$ in Equation (1) was adjusted iteratively using the input signal (snowmelt) described in the previous section to minimize the following least squares statistic (Maloszewski and Zuber, 1996; McGuire et al., 2002):

$$
\sigma=\left[\sum_{i=1}^{n}\left(O_{i}-X_{i}\right)^{2}\right]^{1 / 2}
$$


where $O_{i}$ are observed output (streamflow) $\delta^{18} \mathrm{O}$ values and $X_{i}$ are the model simulated $\delta^{18} \mathrm{O}$ values with $n$ being the number of observations. The $\tau_{\mathrm{m}}$ that minimized Equation (3) for each catchment was assumed to provide the best fit and was adopted as the snowmelt water MTT for that catchment. We report the Nash-Sutcliffe efficiency (NSE) (Nash and Sutcliffe, 1970) and the corresponding 5th/95th percentiles of the exponential distributions for the resulting best fit (Table I) as a metric of goodness of fit. In addition, we consider the uncertainty associated with the MTTs by observing the convergence of the objective function (namely, Equation (3)). By convergence, we mean how quickly the least squares statistic approaches a minimum value. To do this, we consider the influence of a 5\% increase in the minimized least squares statistic and report the corresponding range of estimated snowmelt water MTTs. This gives in a narrower range of estimated MTT for the catchments with more convergent objective functions.

It should be noted that in this formulation the lumped parameter convolution is expressed in clock-time and not flow-corrected time (e.g., Rodhe et al., 1996) or what could be considered explicitly as a nonsteadystate approach (e.g., Neimi, 1977). We were limited (practically) in this respect as discharge during the period considered in this study was available for only 1 of the 15 Krycklan catchments. Using flow-corrected time based on one single discharge time series might change the estimated absolute MTT values, but it likely would have little influence on the relative differences between catchments MTTs. Here, we let the simplicity of the lumped parameter approach and the uniqueness of the dataset that is available for comparisons among the catchments outweigh the uncertainty due to assumptions regarding absolute transit-time estimates.

\section{Catchment characteristics and structure}

Topographic analysis. For topographic factors in this study (Table II), we take the suite of indices considered by Tetzlaff et al. (2009b). As there are many possible indices, we consider this a sufficient cross section of what could be considered 'basic' indices. A raster digital elevations model (DEM) with a $10-\mathrm{m}$ resolution was used for analysis of topographic characteristics. A stream network was generated from the DEM based on the accumulated upslope area and assuming a threshold area of 5 ha for stream initiation. Using this stream network, the median catchment area was computed as the median of the local catchment areas of all stream pixels upstream of the catchment outlet. Each pixel was linked to the stream pixel to which it drained by assuming that the flow path follows the surface topography using a multidirectional flow algorithm (Seibert and McGlynn, 2007). On the basis of this flow path, five indices were computed for each pixel: the elevation above the stream, the distance from the stream, the average gradient along the flow pathway to the stream and the ratio of the flow path length and gradients, which is often considered a proxy for travel times, summed along the entire flow

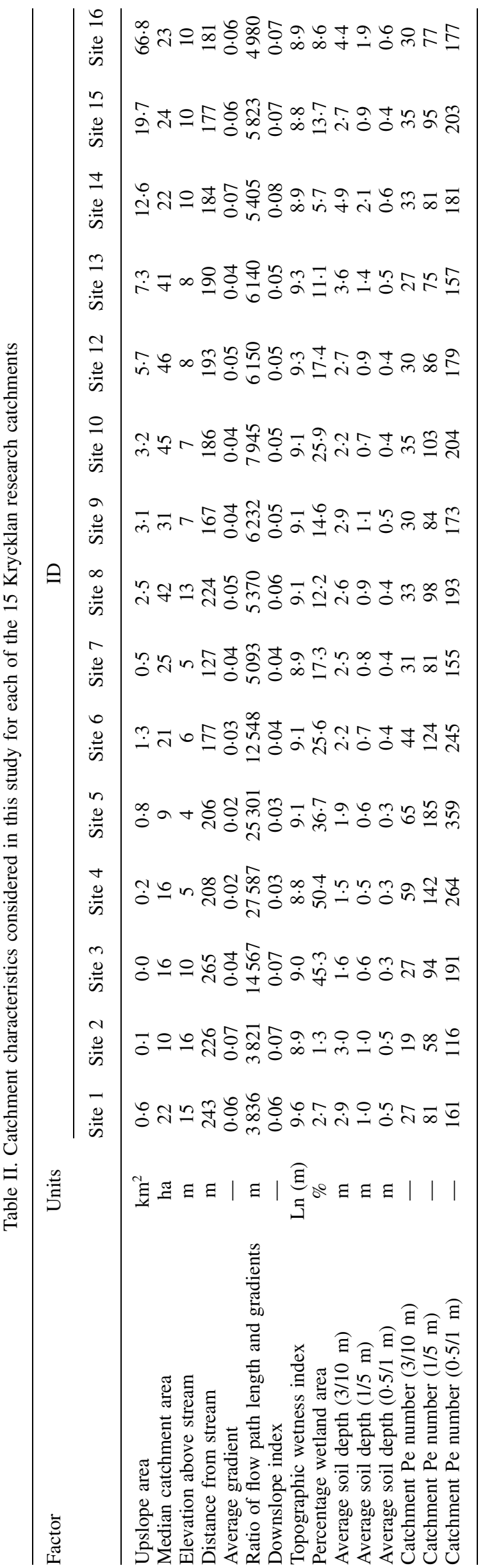


pathway. In addition, the downslope index (Hjerdt et al., 2004) was defined as the gradient towards the closest point, which is at least $5 \mathrm{~m}$ (in altitude) below the pixel in question. The upslope area and slope were combined into the topographic wetness index $(\ln [a / \tan (\beta)])$ similar to Beven and Kirkby (1979), where $a$ is the upslope area per unit contour length and $\tan (\beta)$ is the local slope with the difference that here $\tan (\beta)$ was defined using the downslope index (Hjerdt et al., 2004). For each of these indices considered, catchment-wide median values were computed to represent each of the catchments. Interested readers are referred to Tetzlaff et al. (2009b) for complete methodological procedures.

Landscape analysis. In addition to these topographic factors, we considered other landscape factors (Table II) based on experience within the region. Motivated by the work of Laudon et al. (2007), the percentage of area in each catchment covered by mire wetland was determined. Using the local soil classification map, the average soil depth for each of the catchments was estimated. This factor is included because soils and soil storage have been seen as dominating controls on catchment MTTs in regions with similar geomorphic settings (e.g. Hrachowitz et al., 2009a). Soil depth is a difficult property to estimate as it requires subsurface estimations as opposed to the previous measures that can be estimated from DEM or map analysis. As a high-resolution detailed mapping of soil depth was not available, we considered three potential combinations of soil depths for each of the two dominant soil classes (tills and sediments) based on field observations. For the thinner till soils located in upland regions dominated by unsorted till and for the deeper low-lying sediments, these potential soil depth combinations were considered as $3 / 10,1 / 5,0.5 / 1 \mathrm{~m}$ for the till/sediment soil depths, respectively. These three combinations are assumed to cover the range from the deepest possible soil profiles-where tills are $3 \mathrm{~m}$ deep and sediments are $10 \mathrm{~m}$ deep - to the shallowest possible soil profiles where tills and sediments are 0.5 and $1 \mathrm{~m}$ deep respectively. Finally, we adopt very shallow soil depths $(1 \mathrm{~cm})$ in the mire wetlands based on winter and spring thaw field observations (Laudon et al., 2007) to simulate the influence of impervious ice layers that currently form during winter and snowmelt periods. These wetland ice layers are persistent during the spring thaw period of the year and heavily influence the resulting hydrologic response of the landscape. The soil depth for each catchment was taken as an area-weighted average of the depths of soils in the catchment.

Similarity analysis. By 'similarity', we mean a quantifiable parameter capable of discerning how similar or dissimilar catchments are with respect to their hydrological response (Wagener et al., 2007). While many potential similarity parameters are available to investigate structure (e.g. Sivapalan et al., 1987; Harman and Sivapalan, 2009), we adopt a catchment Péclet number
(Pe) (Lyon and Troch, 2009) number based on the hillslope Pe number (Berne et al., 2005; Lyon and Troch, 2007). Here, we mean structure in terms of both geomorphology (spatial variability of slope, aspect and shape of the land surface) and pedology (spatial variability of soil depth, soil structure and hydraulic properties). This subsurface flow similarity parameter should provide an adequate representation of the underlying physics (to a first-order approximation where hillslopes are characterized by relatively shallow soils underlain by impermeable bedrock, streamlines are essentially parallel to the impervious bedrock, storage in the unsaturated zone has a negligible delaying effect on subsurface flow response and there is a general absence of overland flow) behind the hydrologic responses for catchments in the size range and geomorphologic setting considered in this study.

The dimensionless Péclet number (Pe) is a hillslopescale similarity parameter that defines the ratio of the diffusive flow scale and advective flow time scale in an unconfined sloping aquifer (Brutsaert, 1994; Troch et al., 2004):

$$
\mathrm{Pe}=\left(\frac{L}{2 p D}\right) \tan \alpha-\left(\frac{a_{\mathrm{c}} L}{2}\right)
$$

where $L$ is the hillslope length, $\alpha$ is the hillslope angle, $D$ is soil depth, $p$ is a linearization parameter and $a_{\mathrm{c}}$ is the hillslope plan shape convergence rate.

To estimate Pe numbers at a catchment-scale for each of the 15 Krycklan research catchments (Table II), we used an area-weighted average of the hillslope Pe numbers (Equation (4)) of the individual hillslopes making up each catchment (Lyon and Troch, 2009):

$$
\text { catchment } \mathrm{Pe}=\frac{\sum_{i=1}^{n} A_{\mathrm{h}_{i}} \mathrm{Pe}_{i}}{\sum_{i=1}^{n} A_{\mathrm{h}_{i}}}
$$

where $A_{\mathrm{h}}$ is the individual hillslope area for each of the $n$ hillslopes in a given catchment. Lyon and Troch (2009) demonstrated that using an area-weighted average of the hillslope Pe numbers to generate a catchment-scale Pe number agreed with the hydrologic response (represented using the moments of a characteristic response) as well as using a storage volume-weighted value when considering Pe numbers of the scale found in real-world landscapes.

Hillslopes were delineated and defined using the techniques given by Bogaart and Troch (2006) and Lyon and Troch (2007). The individual hillslope area $\left(A_{\mathrm{h}}\right)$, angle $(\alpha)$ and length $(L)$ were determined using topographic analysis on the DEM. The hillslope convergence rate $\left(a_{\mathrm{c}}\right)$ for each individual hillslope was determined assuming exponential or uniform width functions (Troch et al., 2003; Berne et al., 2005; Lyon and Troch, 2007). The linearization parameter $(p)$ was defined using a theoretical value of 0.30 (Brutsaert, 1994). The soil depth $(D)$ for each hillslope was taken as an area-weighted average of the soils in the hillslope determined from a local soil classification 
map with three potential soil depth combinations considered at 3/10,1/5, 0.5/1 $\mathrm{m}$ for the till/sediment soil depths, respectively, while very shallow soil depths $(1 \mathrm{~cm})$ were taken in the mire wetlands based on winter and spring thaw observations (Laudon et al., 2007). This approach creates three sets of catchment Pe numbers for each of the 15 Krycklan catchments based on variations in assumed soil depths.

\section{RESULTS}

\section{Isotope time series and catchment MTT estimates}

Time series of observed $\delta^{18} \mathrm{O}$ values provide a characterization of the input and output signals to the Krycklan research catchments (Figure 2). A previous work shows that short-term data can lead to highly variable estimates of MTTs when the observation record is short relative to the length of transit times in the catchment (Tetzlaff et al., 2007; Hrachowitz et al., 2009b). In this study, we are estimating the snowmelt water MTTs for a given year of observations. We expect the estimated snowmelt water MTT to vary between years depending on many factors (e.g. amount of snowfall, timing and duration of melt) and do not assume that the snowmelt water MTTs empirical estimated here are time-invariant such that they are constant across all snowmelt seasons. The purpose of this study is to observe relative differences between catchments rather than estimating absolute MTT.

The snowmelt water MTTs range from 10 days for site 4 to 133 days for site 2 , adopting a constant isotopic value of $-16.0 \%$ to represent snowmelt water (Table I). Using this input signal, the average snowmelt water MTT for the Krycklan catchments is 54 days with a standard deviation of 28 days. The NSE for the simulated output time series using exponential transit-time functions range from 0.38 to 0.85 with an average of 0.67 for the 15 Krycklan catchments. The snowmelt water MTTs range from 19 days for site 4 to 180 days for site 2, adopting an enrichment in the snowmelt isotopic value increasing linearly from $-17.9 \%$ o representing the average of the first melt water leaving the snow pack to $-15.6 \%$ o representing the average of the last melt water leaving the snow pack (Table I). Using this input signal, the average snowmelt water MTT for the Krycklan catchments is 76 days with a standard deviation of 38 days. The NSE for the simulated output time series using exponential transit time functions range from 0.35 to 0.82 with an average of 0.65 for the 15 Krycklan catchments. The ranges of MTTs obtained by increasing the minimized least squares statistic by $5 \%$ shows that the convergence of the objective function varies across the 15 Krycklan catchments. This is regardless of the input signal used.

For both input signals, the sites with the highest MTT (site 2) and the lowest MTT (site 4) are located within about $1 \mathrm{~km}$ and the catchments are similar with regards to upslope area. Despite this proximity in space and similarity in size, the range of snowmelt water MTTs covers 1 order of magnitude. The main difference between sites 2 and 4 is the landscape characteristics (Table II). In addition, site 4 has a larger percentage covered by mire wetlands than site 2 . Site 4 has one of the largest percentage areas covered by mire wetlands of any of the 15 Krycklan catchments. Site 2 has a deeper soil profile (on average) based on the estimate used in this study than site 4 .

There is a difference in estimated MTTs due to the adoption of a constant isotopic snow melt water value versus a value that enriches linearly over the snowmelt period (Figure 3). There is an average increase of about $33 \%$ using the linear enriching isotopic signal over the constant isotopic input signal. This increase, however, maintains the relative differences between individual catchment snowmelt water MTTs. While this demonstrates some of the uncertainty associated with the absolute estimated snowmelt water MTTs due to the representation of the input signal, it shows the insensitivity in the relative differences among the catchments. As such, we adopt the MTTs estimated using the constant snow melt isotopic values for the remainder of this study as we are primarily interested in the relationship between MTTs and the landscape and not the absolute estimate of MTTs.

\section{Empirical relations between landscape and snowmelt MTT}

The 15 Krycklan catchments have a range of characteristic values (Table II). Sites draining the upper portion of the study area (e.g. sites 3, 4, 5 and 6) tend to have lower average gradients and larger percentage of their total area covered with mire wetlands. This leads to relatively high ratios of flow path length to gradient for these catchments. These low gradients are reflected by low average elevations above the stream. While these sites have somewhat low downslope indices relative to the other Krycklan sites, their catchment-average topographic wetness indices fall approximately in the middle

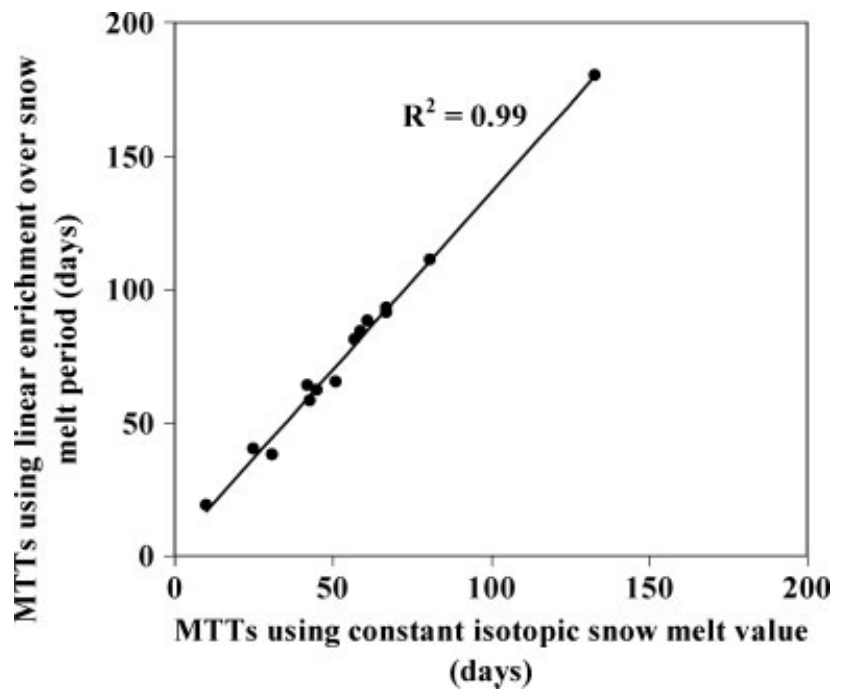

Figure 3. Influence of representing snow melt water as a constant isotopic value versus using a linear enrichment over the snow melt period. The slope of the line is $33 \%$ 
of those reported for the other Krycklan catchments. The catchment-average estimated soil depths in this upper portion of the study area (e.g. sites 3, 4, 5 and 6) tend to be lower than those in other regions. This reflects the skewed distribution of till and sediment soils such that tills are more prevalent in the upper portion of the main catchment. Catchment Pe numbers (Table II) for all 15 Krycklan catchments vary across the study area. Considering the middle soil depth profiles $(1 / 5 \mathrm{~m}$ till/sediment soil depths), for example, catchment Pe numbers for the Krycklan catchments range from 58 for site 2 to 185 for site 5 with an average of 98 for all sites. Again, the upper portion of the study area in general has similar (higher) catchment Pe numbers. This is expected as this similarity parameter contains soil depth, gradient and flow path lengths in its definition and, therefore, incorporates both topographic factors and landscape factors in its description of catchment structure.

Each of the catchment characteristics listed in Table II can be empirically related to the snowmelt water MTTs estimated for the 15 Krycklan catchments (Table III). Using linear trends, there are significant $(p<0.02)$ relationships between snowmelt MTTs and several of the characteristics. These characteristics include topographic factors (average gradient and ratio of flow path length to gradient), some landscape factors (percentage wetland area and soil depth assuming the shallowest soil profiles) and all of the catchment Pe numbers. Of these significant trends, the percentage wetland area covering the catchment has the highest coefficient of determination $\left(R^{2}=0 \cdot 59\right)$.

Table III. Linear regressions relating snowmelt water MTTs and all landscape factors

\begin{tabular}{|c|c|c|}
\hline Factor & Linear regression & $R^{2}$ \\
\hline Upslope area & $\tau_{m}=0.37 X+51.43$ & 0.05 \\
\hline Median catchment area & $\tau_{m}=-0 \cdot 22 X+60 \cdot 16$ & 0.01 \\
\hline Elevation above stream & $\tau_{m}=5 \cdot 28 X+7.03$ & 0.05 \\
\hline Distance from stream & $\tau_{m}=-0.02 X+58.50$ & 0.00 \\
\hline Average gradient & $\tau_{m}=1333.00 X-6.45$ & 0.52 \\
\hline $\begin{array}{l}\text { Ratio of flow path } \\
\text { length and gradients }\end{array}$ & $\tau_{m}=-0 \cdot 0024 X+77 \cdot 43$ & 0.43 \\
\hline Downslope index & $\tau_{m}=1010 \cdot 80 X-1.60$ & $0 \cdot 29$ \\
\hline $\begin{array}{l}\text { Topographic wetness } \\
\text { index }\end{array}$ & $\tau_{m}=2 \cdot 48 X+32 \cdot 01$ & 0.00 \\
\hline Percentage wetland area & $\tau_{m}=-1.45 X+82.31$ & 0.59 \\
\hline $\begin{array}{l}\text { Average soil depth } \\
\qquad(3 / 10 \mathrm{~m})\end{array}$ & $\tau_{m}=14.33 X+14.63$ & $0 \cdot 22$ \\
\hline $\begin{array}{l}\text { Average soil depth } \\
(1 / 5 \mathrm{~m})\end{array}$ & $\tau_{m}=23 \cdot 11 X+31 \cdot 07$ & $0 \cdot 14$ \\
\hline $\begin{array}{l}\text { Average soil depth } \\
((0 \cdot 5 / 1 \mathrm{~m})\end{array}$ & $\tau_{m}=172 \cdot 31 X+19 \cdot 82$ & 0.39 \\
\hline $\begin{array}{l}\text { Catchment Pe number } \\
(3 / 10 \mathrm{~m})\end{array}$ & $\tau_{m}=-1 \cdot 42 X+104 \cdot 62$ & 0.39 \\
\hline $\begin{array}{l}\text { Catchment Pe number } \\
(1 / 5 \mathrm{~m})\end{array}$ & $\tau_{m}=-0.57 X+109 \cdot 57$ & 0.40 \\
\hline $\begin{array}{l}\text { Catchment Pe number } \\
((0.5 / 1.0 \mathrm{~m})\end{array}$ & $\tau_{m}=-0 \cdot 31 X+116 \cdot 22$ & $\mathbf{0 . 4 0}$ \\
\hline
\end{tabular}

In the linear regression equations, $X$ signifies the factor as the independent variable and $\tau_{\mathrm{m}}$ is the MTT. Bold text indicates $p<0.02$ significance.
There are positive relationships between both catchment-average gradients and average soil depths and snowmelt water MTTs. Negative relationships were found between the flow path length over gradient, percentages of mire wetland area and catchment Pe numbers and the estimated snowmelt water MTTs. In general, catchments covered to a larger extent with mire wetlands have lower (faster) snowmelt water MTTs. In addition, catchments containing low gradients and shallow soils have lower (faster) snowmelt water MTTs. Note that both average gradient and soil depth are significantly correlated (or perhaps more appropriately co-vary) with percentage wetland area. While this correlation is somewhat spurious for soil depth as the estimated catchmentaverage soil depths (in this study) are a function of mire wetland area, it is independent of the connection between gradients and mire wetlands.

These connections between topographic factors and landscape factors and the snowmelt water MTT are captured in the relation between catchment Pe number and the snowmelt water MTT. As a catchment has a lower Pe number (i.e. the influence of advective time scale increases), there is a corresponding increase in snowmelt water MTT. This relation shows that the catchment Pe number is properly representing the physics governing shallow subsurface flow in the Krycklan research catchments. The relative relationship between the catchment Pe numbers of the individual catchments is conserved under the different soil depth profile combinations considered. As such, even if the absolute catchment Pe numbers for the Krycklan catchments are not known explicitly, we can still use the relative relationship between the catchment Pe numbers in a similarity approach to compare the relationship between snowmelt water MTTs and catchment structure among the different catchments.

\section{A POSSIBLE INFLUENCE OF CLIMATIC CHANGES: A THOUGHT EXPERIMENT}

We can take advantage of the relationship between catchment structure and hydrologic response to present a simple thought experiment to explore how climate change can restructure catchments in ways that influence the hydrology. The empirical relationships between catchment structure and snowmelt hydrologic response (Table III) mimic a present-day scenario by assuming the soil depth in all mire wetlands during snowmelt at Krycklan to be $1 \mathrm{~cm}$. This depth is similar to the observed impervious wetland ice layers for this region (Laudon et al., 2007). While these ice layers are temporally dynamic in that they melt seasonally as spring thaw moves into a warmer summer period, they exhibit a strong control on flow pathways during the spring melt period of the year (Laudon et al., 2007). As such, estimating catchment Pe numbers assuming wetland soil depths of $1 \mathrm{~cm}$ provides a method to effectively capture the first-order structural control of wetland soil ice on the snowmelt hydrological response. The empirical relationship between the catchment Pe numbers and snowmelt 
water MTTs can be used to estimate the potential influence of changes in the internal catchment structure.

We can recalculate catchment Pe numbers for each catchment assuming the soil depth in the wetlands to be $30 \mathrm{~cm}$ deep. This could be assumed to simulate an icefree mire wetland during snowmelt. Assuming effectively deeper wetlands, there is a corresponding decrease in catchment Pe number across catchments. Using these new catchment Pe numbers and the empirical relationships defined in Table III, we can estimate the potential change in snowmelt water MTTs for the Krycklan catchments under a scenario where no wetland ice forms. This leads to a corresponding increase in the snowmelt water MTTs ranging from $20 \%$ on average to $45 \%$ on average using $3 / 10 \mathrm{~m}$ or the $0.5 / 1 \mathrm{~m}$ till/sediment soil depths, respectively.

\section{DISCUSSION}

The snowmelt water MTTs empirically estimated for the 15 Krycklan catchments represent a specific component of the many different transit times of sources of water active at the catchment scale. As recently observed by Sayama and McDonnell (2009), there are limitations in estimating time-invariant transit-time distributions with no ability to quantify the dynamics of the distributions with flow conditions and rainfall regimes. This echoes the empirical findings of Tetzlaff et al. (2007) and Hrachowitz et al. (2009b) with respect to variations in long-term catchment MTTs. Still, it may by useful to estimate the MTTs for some source water components of the catchment-scale transit-time distribution. Dunn et al. (2007) highlighted this usefulness in that each specific component transit time with respect to water sources may be related to characteristic properties of a catchment. Such relations could form the basis for conceptualizations of how component MTTs may evolve in response to shifts in flow conditions and precipitation regimes. For example, subsurface ice in northern climates directly influences the distribution of hydrologic pathways in the landscape and, as such, its thawing could change component MTTs. Such thawing could be considered as a more long-term process (e.g. permafrost loss) or could occur in shorter, more discrete intervals (e.g. lack of ice layer formation in boreal wetlands).

The methodology used in this study provides an estimate of the MTTs associated with the movement of snowmelt water through the shallow subsurface. This is accomplished through characterization of the isotopic input signal such that we represent the snowmelt water uniquely from a background signature of baseflow waters. Of course, this is a simplified approach to the problem as there is likely mixing between snowmelt water and deeper flow paths which maintain this baseflow water. Uncertainty is also associated with how one represents the input signal of the snowmelt water (Figure 3). While this seems to influence the absolute MTTs estimates in this study, it does not significantly influence the relative differences among the catchments. There are uncertainties in the absolute magnitude of the estimated snowmelt water MTTs due to simplifying assumptions made intrinsically when applying this lumped parameter convolution approach. However, the results of the lumped parameter modelling in this system seem appropriate and there is general agreement between modelled output and stream observed $\delta^{18} \mathrm{O}$ values (Table I). This general agreement (in part) is conditioned by the incorporation of stream observations into the input signal used in the lumped parameter convolution approach. In addition, the estimated snowmelt water MTTs can be related to landscape and topographic factors such that there is agreement between the estimated MTTs and the conceptualization laid out by Laudon et al. (2007). This gives some additional confidence that the methodology used in this study is applicable under these snowmeltdominated conditions.

Several of the catchment characteristics representing topographic and landscape factors investigated in this study can be related to the snowmelt MTTs for the Krycklan catchments (Table III). Laudon et al. (2007) demonstrated a strong connection between the wetland area in these catchments and the flow path distribution. Similar to this, this study found the strongest connection (highest $R^{2}$ ) for a linear relationship between snowmelt MTTs and wetland area. Catchments covered by more mire wetlands have faster snowmelt water MTTs. In addition, there is a significant $(p<0.02)$ linear relation between topographic features (primarily gradient) and the snowmelt water MTTs. Counter to the typical topographic-driven controls on MTTs (e.g. McGuire et al., 2005), in this boreal system, catchments with steeper gradients (lower flow path length to gradient ratios) have longer snowmelt water MTTs. As such, these northern Swedish catchments appear to behave similar (with respect to topographic controls on transit times) to the Scottish Highland catchments (Tetzlaff et al., 2009b). Taken together, it can be seen that these landscape and topographic factors are related (Buttle, 2006; Tetzlaff et al., 2009b). That is, wetlands with responsive soils (Bishop et al., 2004; Soulsby et al., 2006b) and/or near-surface impervious ice layers during snowmelt (Laudon et al., 2007) co-evolve with landscape positions with lower gradients. This is conceptually similar to relationships found between aspect and evolution of transit times in several small, mountainous catchments by Broxton et al. (2009).

In general, there are significant $(p<0.02)$ relationships between evaluated snowmelt water MTTs and the calculated catchment Pe numbers for the Krycklan catchments (Table III). This is not very surprising as the Pe number (used as a similarity parameter) should be able to discern responses in a given hydrological setting based solely on the catchment structure (Berne et al., 2005; Lyon and Troch, 2007) and should be able to incorporate several of the factors that were significantly related to snowmelt water MTTs into one parameter. One utility of considering such a physics-based similarity parameter 
is that it allows for the development of a functional relationship between the hydraulic theory and a catchment's pedo-geomorphological structure. As such, the information contained in such a similarity parameter can be generalized to the traditional hydrologic theory and can be transferred to other locations. Similarity parameters like the catchment Pe number, therefore, have promise with respect to classification schemes for grouping similar small catchments on the basis of the hydrological response. Of course, there are numerous complexities in the Krycklan catchments that complicate and encumber any direct prediction of snowmelt hydrologic response at the small-catchment scale using the catchment Pe number. The catchment Pe number merely provides an empirical relationship between catchment structures to the snowmelt water hydrologic response in the Krycklan research catchments.

This relation between catchment structure and snowmelt water hydrologic response allows some investigation of the influence of climatic changes to ice layers on hydrologic response in these catchments. In this study, we approach this using a simple thought experiment (Section on A Possible Influence of Climatic Changes: A Thought Experiment). This thought experiment does not take into consideration (directly) the possible role of soil hydraulic properties. For example, there is likely a decrease in hydraulic conductivity with depth in the wetlands. As such, subsurface water may not infiltrate through to a depth of $30 \mathrm{~cm}$ before flowing laterally as these soils and landscape positions tend to be rather hydrologically reactive (Soulsby et al., 2006b). It is possible that the actual effect of the lack of a wetland soil ice layer may be less than that predicted via our simple thought experiment. In addition, other competing changes may occur under conditions where ice layers do not form (i.e. changes in winter time precipitation form, changes in amount of snow cover and changes in the timing of the melt). While this thought experiment only allows us to roughly estimate the potential change in hydrologic response due to wetland ice layer thawing, it should be noted that any actual thawing of subsurface ice layers will influence flow pathway distributions in northern boreal catchments. Even a modest-to-small shift in flow pathways may greatly influence biogeochemical cycling and/or hydrologic response in these boreal systems (e.g. Bishop et al., 2004; Klaminder et al., 2006).

Our goal in presenting this wetland ice layer thawing thought experiment is to provide a framework from which we can begin considering the structure of a catchment as a more dynamic system capable of evolving or changing in the time scale of human observation. This is important with regards to the climatic change and its effect on the hydrologic cycle at northern latitudes. It highlights that the various component MTTs that constitute a catchment's long-term MTT may evolve differently in the future. For example, the estimated influence of wetland soil ice is somewhat counter-intuitive in terms of a snowmelt water MTT shift to what might be expected due to climate change. Typically, climate change is expected to be accelerating the hydrologic cycle (warmer and wetter) in most northern regions (Peterson et al., 2002; Déry et al., 2005) and, thus, we could expect faster catchment MTTs in general due to shifts in the forcing. However, these shifts in catchment forcing may (to some extent) be countered by possible shifts in catchment structure that lead to a dampened hydrologic response. It is therefore likely that climate change presents competing influences on catchment component MTTs that need to be considered. While some component MTTs could tend to decrease due to accelerations in the climatic forcing, some could tend to increase due to changes in the catchment structure or shifts in flow pathways. The balance between these competing influences might have consequences on climatic feedbacks at the catchment scale and warrants further investigation.

\section{CONCLUDING REMARKS}

In this study, we estimated snowmelt water MTTs for the 15 Krycklan research catchments located in northern Sweden. Among the different tested catchment indices, snowmelt water MTTs had the highest correlation with the percentage mire wetland area. An empirical model using the catchment Pe number was formulated and used to estimate the potential influence of wetland ice layers on hydrologic response. From this simple thought experiment, there is a potential increase on average of 20 to $45 \%$ in snowmelt water MTTs under a scenario when no ice layers form in wetlands. This highlights that the snowmelt water MTTs, and thus also the catchment long-term MTT, may exhibit competing influences on the hydrological and biogeochemical cycles of this and (potentially) other boreal regions.

\section{ACKNOWLEDGEMENTS}

The lead author (SL) would like to acknowledge support in the form of funding from the Swedish Research Council (VR) and the Bert Bolin Centre for Climate Research, which is supported by a Linnaeus grant from VR and The Swedish Research Council Formas. We also acknowledge the support to the Krycklan Catchment Study from VR and Formas.

\section{REFERENCES}

Ågren A, Buffam I, Jansson M, Laudon H. 2007. Importance of seasonality and small streams for the landscape regulation of DOC export. Journal of Geophysical Research-Biogeosciences 112: G03003. DOI: 10.1029/2006 JG000381.

Barnes CJ, Bonell M. 1996. Application of unit hydrograph techniques to solute transport in catchments. Hydrological Processes 10(6): 793-802. DOI:10.1002/(SICI)1099-1085(199606)10:6<793::AIDHYP372>3.0.CO;2-K.

Berne A, Uijlenhoet R, Troch PA. 2005. Travel time distributions of subsurface flow along complex hillslopes with exponential width functions. Water Resources Research 41: W09410. DOI: 10.1029/2004WR003629. 
Beven KJ, Kirkby MJ. 1979. Towards a simple, physically based, variable contributing area model of catchment hydrology. International Association of Hydrological Sciences Bulletin 24: 43-69.

Bishop KH, Grip H, O'Neill A. 1990. The origin of acid runoff in a hillslope during storm events. Journal of Hydrology 116: 35-61.

Bishop K, Seibert J, Köhler S, Laudon H. 2004. Resolving the Double Paradox of rapidly mobilized old water with highly variable responses in runoff chemistry. Hydrological Processes 18: 185-189. DOI: 10.1002/hyp.5209.

Bogaart PW, Troch PA. 2006. Curvature distribution within hillslopes and catchments and its effect on the hydrological response. Hydrology and Earth System Sciences 10: 925-936.

Broxton PD, Troch PA, Lyon SW. 2009. On the role of aspect to quantify water transit times in small mountainous catchments. Water Resources Research 45: W08427. DOI:10.1029/2008WR007438.

Brutsaert W. 1994. The unit response of groundwater outflow from a hillslope. Water Resources Research 30(10): 2759-2763.

Buffam I, Laudon H, Temnerud J, Mörth C-M, Bishop K. 2007. Landscape-scale variability of acidity and dissolved organic carbon during spring flood in a boreal stream network. Journal of Geophysical Research 112: G01022. DOI: 10.1029/2006JG000218.

Buttle J. 2006. Mapping first-order controls on streamflow from drainage basins: the $\mathrm{T}^{3}$ template. Hydrological Processes 20: $3415-3422$.

Carey SK, Woo MK. 2001. Slope runoff processes and flow generation in a subarctic, subalpine catchment. Journal of Hydrology 253: 110-129.

Coplen TB. 1995. Reporting of stable hydrogen, carbon and oxygene isotopic abundances. Geothermics 24: 707-712.

Déry SJ, Stieglitz M, McKenna EC, Wood EF. 2005. Characteristics and trends of river discharge into Hudson, James, and Ungava Bays, 1964-2000. Journal of Climate 18: 2540-2557.

Dunn SM, McDonnell JJ, Vache KB. 2007. Factors influencing the residence time of catchment waters: A virtual experiment approach. Water Resources Research 43: W06408. DOI:10.1029/2006WR005393.

Harman CJ, Sivapalan M. 2009. A similarity framework to assess controls on shallow subsurface flow dynamics. Water Resources Research 45: W01417. DOI: 10.1029/2008WR007067.

Hinzman LD, Kane DL, Everett KR. 1993. Hillslope hydrology in an Arctic setting. Proceedings, Sixth International Conference on Permafrost. South China Press: Beijing; 257-271.

Hrachowitz M, Soulsby C, Tetzlaff D, Dawson JJC, Malcolm IA. 2009a. Regionalization of transit time estimates in montane catchments by integrating landscape controls. Water Resources Research 45: W05421. DOI: $10.1029 / 2008$ WR007496.

Hrachowitz M, Soulsby C, Tetzlaff D, Dawson JJC, Dunn SM, Malcolm IA. 2009b. Using longer-term data sets to understand transit times in contrasting headwater catchments. Journal of Hydrology 367(3): $237-248$.

Hjerdt KN, McDonnell JJ, Seibert J, Rodhe A. 2004. A new topographic index to quantify downslope controls on local drainage. Water Resources Research 40: W05602. DOI:10.1029/2004WR003130.

Kane DL, Bredthauer SR, Stein J. 1981. Subarctic snowmelt runoff generation. In Proceedings of the Specialty Conference on the Northern Community, Vinson TS (ed.). American Society of Civil Engineers: Seattle, WA; 591-601.

Kirchner JW, Feng X, Neal C. 2000. Fractal stream chemistry and its implications for contaminant transport in catchments. Nature 403(6769): 524-527. DOI:10.1038/35000537.

Kirchner JW, Feng X, Neal C. 2001. Catchment-scale advection and dispersion as a mechanism for fractal scaling in stream tracer concentrations. Journal of Hydrology 254: 82-101.

Klaminder J, Bindler R, Laudon H, Bishop K, Emteryd O, Renberg I. 2006. Flux rates of atmospheric lead pollution within soils from a small catchment in northern Sweden and their implication for future stream water quality. Environmental Science and Technology 40: 4639-4645.

Köhler SJ, Buffam I, Laudon H, Bishop KH. 2008. Climate's control of intra-annual and inter-annual variability of total organic carbon concentration and flux in two contrasting boreal landscape elements. Geophysical Research Biogeosciences 113: G03012. DOI: 10.1029/2007JG000629.

Laudon H, Köhler S, Seibert J, Bishop KH. 2004. Hydrological flow paths during the spring flood: Congruence between hydrometric measurements and oxygen-18 in snow melt, soil water, and runoff. Water Resources Research 40(3): W03102. 10.1029/2003WR002455.

Laudon H, Sjöblom V, Buffam I, Seibert J, Mörth M. 2007. The role of catchment scale and landscape characteristics for runoff generation of boreal streams. Journal of Hydrology 344: 198-209.

Lyon SW, Destouni G. 2009. Changes in catchment-scale recession flow properties in response to permafrost thawing in the Yukon
River Basin. International Journal of Climatology (in press), DOI: 10.1002/joc. 1993.

Lyon SW, Troch PA. 2007. Hillslope subsurface flow similarity: realworld tests of the hillslope Péclet number. Water Resources Research. 43: W07450. DOI: 10.1029/2006WR005323.

Lyon SW, Troch PA. 2009. Development and application of a catchment similarity index for subsurface flow. Water Resources Research in review.

Lyon SW, Desilets SLE, Troch PA. 2008. Characterizing the response of a catchment to an extreme rainfall event using hydrometric and isotopic data. Water Resources Research 44: W06413. DOI: 10.1029/2007WR006259.

Lyon SW, Destouni G, Giesler R, Humborg C, Mörth M, Seibert J, Karlsson J, Troch PA. 2009. Estimation of permafrost thawing rates in a sub-arctic catchment using recession flow analysis. Hydrology and Earth System Sciences 13: 595-604.

Maloszewski P, Zuber A. 1982. Determining the turnover time of groundwater systems with the aid of environmental tracers: 1 . Models and their applicability. Journal of Hydrology 57: 207-231. DOI:10.1016/0022-1694(82)90147-0.

Maloszewski P, Rauert W, Stichler W, Herrmann A. 1983. Application of flow models in an alpine catchment area using tritium and deuterium data. Journal of Hydrology 66: 319-330.

Maloszewski P, Zuber A. 1993. Principles and practice of calibration and validation of mathematical models for the interpretation of environmental tracer data. Advances in Water Resources 16: 173-190.

Maloszewski P, Zuber A. 1996. Lumped parameter models for the interpretation of environmental tracer data, in Manual on Mathematical Models in Isotope Hydrogeology, TECDOC-910, Yurtsever Y (ed.). Int. At. Energy Agency: Vienna; 9-58.

McDonnell JJ, Sivapalan M, Vaché K, Dunn SM, Grant G, Haggerty R, Hinz C, Hooper R, Kirchner J, Roderick ML, Selker J, Weiler M. 2007. Moving beyond heterogeneity and process complexity: A new vision for watershed hydrology. Water Resources Research 43 . W07301.

McGlynn B, McDonnell J, Stewart M, Seibert J. 2003. On the relationships between catchment scale and streamwater mean residence time. Hydrological Processes 17(1): 175-181.

McGuire KJ, DeWalle DR, Gburek WJ. 2002. Evaluation of mean residence time in subsurface waters using oxygen-18 fluctuations during drought conditions in the mid- Appalachians. Journal of Hydrology 261: 132-149. DOI:10.1016/S0022-1694(02)00006-9.

McGuire KJ, McDonnell JJ. 2006. A review and evaluation of catchment transit time modeling. Journal of Hydrology 330: 543-563.

McGuire KJ, McDonnell JJ, Weiler M, Kendall C, Welker JM, McGlynn BL, Seibert J. 2005. The role of topography on catchment-scale water residence time. Water Resources Research. 41(5): W05002. DOI: 10.1029/2004WR00365.

McNamara JP, Kane DL, Hinzman LD. 1997. Hydrograph separations in an Arctic watershed using mixing model and graphical techniques. Water Resources Research 33(7): 1707-1719.

McNamara JP, Kane DL, Hinzman LD. 1998. An analysis of streamflow hydrology in the Kuparuk River Basin, Arctic Alaska: a nested watershed approach. Journal of Hydrology 206: 39-57.

Nash JE, Sutcliffe VJ. 1970. River flow forecasting through conceptual models: I. A discussion of principles. Journal of Hydrology 10: 282-290. DOI: 10.1016/0022-1694 (70)90255-6.

Niemi AJ. 1977. Residence time distribution of variable flow processes. International Journal of Applied Radiation and Isotopes 28: 855-860.

Niemi AJ. 1977. Residence time distribution of variable flow processes. International Journal of Applied Radiation and Isotopes 28: 855-860. DOI:10.1016/0020-708X(77)90026-6.

Ottosson-Löfvenius MO, Kluge M, Lundmark T. 2003. Snow and soil frost depth in two types of shelterwood and a clear-cut area. Scandinavian Journal of Forest Research 18: 54-63.

Peterson BJ, Holmes RM, McClelland JW, Vörösmarty CJ, Lammers RB, Shiklomanov AI, Shiklomanov IA, Rahmstor S. 2002. Increasing river discharge to the Arctic Ocean. Science 298 : $2171-2173$.

Rodhe A, Nyberg L, Bishop K. 1996. Transit times for water in a small till catchment from a step shift in the oxygen 18 content of the water input. Water Resources Research 32(12): 3497-3511.

Roulet NT, Woo MK. 1988. Runoff generation in a low arctic drainage basin. Journal of Hydrology 101: 213-226.

Santeford HS. 1979. Toward hydrologic modeling of the black spruce/permafrost ecosystem of interior Alaska. In Proceedings 30th Alaska Science Conference. Fairbanks, Alaska.

Sayama T, McDonnell JJ. 2009. A new time-space accounting scheme to predict stream water residence time and hydrograph source components 
at the watershed scale. Water Resources Research 45: W07401. DOI: 10.1029/2008WR007549.

Seibert J, McGlynn B. 2007. A new triangular multiple flow direction algorithm for computing upslope areas from gridded digital elevation models. Water Resources Research 43: W04501. DOI: 10.1029/2006WR005128.

Sivapalan M, Beven K, Wood EF. 1987. On hydrologic similarity. 1. A scaled model of storm runoff production: Water Resources Research 23(11): 2266-2278.

Slaughter CW, Kane DL. 1979. Hydrologic role of shallow organic soils in cold climates. Proceedings, Canadian Hydrology Symposium 79-Cold Climate Hydrology. National Research Council of Canada: Ottawa; 380-389.

Soulsby C, Tetzlaff D, Dunn SM, Waldron S. 2006a. Scaling up and out in runoff process understanding - insights from nested experimental catchment studies. Hydrological Processes 20: 2461-2465.

Soulsby C, Tetzlaff D, Rodgers P, Dunn SM, Waldron S. 2006b. Runof processes, stream water residence times and controlling landscape characteristics in a mesoscale catchment: an initial evaluation. Journal of Hydrology 325: 197-221.

Spence C, Woo MK. 2006. Hydrology of sub-arctic Canadian shield: heterogenous headwater basins. Journal of Hydrology 317: 138-154.

Tetzlaff D, Malcolm IA, Soulsby C. 2007. Influence of forestry, environmental change and climatic variability on the hydrology, hydrochemistry and residence times of upland catchments. Journal of Hydrology 346: 93-111.

Tetzlaff D, Seibert J, Soulsby C. 2009a. Inter-catchment comparison to assess the influence of topography and soils on catchment transit times in a geomorphic province; the Cairngorm mountains, Scotland. Hydrological Processes 20: 1874-1886.

Tetzlaff D, Seibert J, McGuire KJ, Laudon H, Burns DA, Dunn SM, Soulsby C. 2009 b. How does landscape structure influence catchmen transit times across different geomorphic provinces? Hydrological Processes 23(6): 945-953.

Troch PA, Carrillo GA, Heidbüchel I, Rajagopal S, Switanek M, Volkmann THM, Yaeger M. 2008. Dealing with landscape heterogeneity in watershed hydrology: a review of recent progress toward new hydrological theory. Geography Compass 2(3): 375-392.

Troch PA, Paniconi C, van Loon E. 2003. Hillslope-storage Boussinesq model for subsurface flow and variable source areas along complex hillslopes: 1. Formulation and characteristic response. Water Resources Research 39: 1316, DOI: 10.1029/2002WR001728.

Troch PA, van Loon E, Hilberts A. 2004. Analytical solution of the linearized hillslope-storage Boussinesq equation for exponential hillslope width functions. Water Resources Research 40: W0860. DOI: 10.1029/2003WR002850.

Wagener T, Sivapalan M, Troch P, Woods R. 2007. Catchment classification and hydrologic similarity. Geography Compass 1: 901-931. DOI:10.1111/j.1749-8198.2007.00039.x.

Woo MK, Kane DL, Carey SK, Yang D. 2008. Progress in permafrost hydrology in the new millennium. Permafrost and Periglacial Processes 19: 237-254.

Yamazaki Y, Kubota J, Ohata T, Vuglinsky V, Mizuyama T. 2006. Seasonal changes in runoff characteristics on a permafrost watershed in the southern mountainous region of eastern Siberia. Hydrological Processes 20: 453-467.

Yurtsever Y, Payne B. 1986. Mathematical models based on compartmental simulation approach for quantitative interpretation of tracer data in hydrological systems. In 5th International Symposium on Underground Water Tracers, Morif A, Paraskevopoulou P (eds). A.A. Balkema: Vermont, USA; 341-353. 